Abstracta Iranica Abstranica

Revue bibliographique pour le domaine irano-aryen

Volume 28 | 2007

Comptes rendus des publications de 2005

\title{
Linguistic Convergence and Areal Diffusion: Case Studies from Iranian, Semitic and Turkic. London - New York, Routledge Curzon, 2005, 373 p.
}

\section{Behrooz Mahmoudi Bakhtyari}

\section{(2) OpenEdition}

Journals

Édition électronique

URL : http://journals.openedition.org/abstractairanica/8792

DOI : 10.4000/abstractairanica.8792

ISSN : 1961-960X

Éditeur :

CNRS (UMR 7528 Mondes iraniens et indiens), Éditions de l'IFRI

Édition imprimée

Date de publication : 15 mai 2007

ISSN : 0240-8910

Référence électronique

Behrooz Mahmoudi Bakhtyari, «Linguistic Convergence and Areal Diffusion: Case Studies from Iranian, Semitic and Turkic. London - New York, Routledge Curzon, 2005, 373 p. », Abstracta Iranica [En ligne], Volume 28 | 2007, document 9, mis en ligne le 18 septembre 2007, consulté le 25 septembre 2020. URL : http://journals.openedition.org/abstractairanica/8792 ; DOI : https://doi.org/10.4000/ abstractairanica.8792

Ce document a été généré automatiquement le 25 septembre 2020.

Tous droits réservés 


\title{
Linguistic Convergence and Areal Diffusion: Case Studies from Iranian, Semitic and Turkic. London - New York, Routledge Curzon, 2005, 373 p.
}

\author{
Behrooz Mahmoudi Bakhtyari
}

This book is partly based on the contributions to a conference convened at Uppsala University in 2001, named Areas of Iranian-Semitic-Turkic Convergence: Linguistic Contact in Western and Central Asia in the Past and Present. The book is composed of four parts (Iranian Languages, Semitic Languages, Turkic Languages, and other Perspectives) with 25 papers, of which five papers concern Iranian languages (cf. c.r. $n^{\circ} 32,39,40,41,42$ ).

\section{INDEX}

Thèmes : 1.2. Recueils d'articles : revues, colloques, ouvrages collectifs

\section{AUTEURS}

BEHROOZ MAHMOUDI BAKHTYARI

Université de Téhéran - Grande Encyclopédie de l'Islam 